\title{
A MINIMUM AGE FOR EARLY DEPICTIONS OF SOUTHEAST ASIAN PRAUS

\author{
in the Rock Art of Arnhem Land, Northern Territory
}

\author{
Paul S.C. Taçon ${ }^{1}$, Sally K. May², Stewart J. Fallon³, Meg Travers², Daryl Wesley ${ }^{4}$ \\ and Ronald Lamilami ${ }^{5}$
}

\begin{abstract}
In 2008, we began two related research projects that focus on recent Australian rock art, made after the arrival of Asians and Europeans, in part of northwest Arnhem Land's Wellington Range. This area has extensive and diverse rock art, including many examples of paintings that reflect contact between local Aboriginal people and visitors to their shores. At some sites figures made of beeswax are found superimposed under and over paintings, thus providing a means of obtaining minimum and maximum ages for pigment art. We report on the results of an initial radiocarbon beeswax dating programme at the Djulirri site complex. Results include the earliest age for a depiction of a Southeast Asian watercraft in Australian rock art, which is also Australia's earliest contact period rock art depiction discovered so far. Based on the probability distribution of the calibrated ages, it is $99.7 \%$ probable this image dates to before AD 1664 and likely is much older. The significance of this result is discussed in relation to early contact history, as revealed by historic documents and archaeological excavation. Other important results suggest a close encounter between local Aboriginal people and Europeans occurred in the 1700s, before British exploration and settlement in the Arnhem Land region.
\end{abstract}

\section{Introduction}

Arnhem Land is renowned for its extensive painted rockshelters, including some which are home to the most recent rock art of northern Australia (Chaloupka 1993; Chippindale and Taçon 1998; Lewis 1988; Taçon 1989). The Wellington Range study area (Figure 1), south of South Goulburn Island, is a particularly significant place for rock art in Arnhem Land, with many recent sites, unique contact period imagery and highly variable subject matter (May et al. 2010). As the northernmost outlier of the Kombolgie Sandstone that forms the famous Arnhem Land Plateau, there are many shelters with contact subject matter associated with Macassans and Europeans visiting the Arnhem coast.

Since mid-2008, over 200 art sites in the centre of the Wellington Range have been documented as part of two ARC-

\footnotetext{
School of Humanities, Gold Coast Campus, Griffith University, QLD 4222, Australia p.tacon@griffith.edu.au

${ }^{2}$ School of Archaeology and Anthropology, Research School of Humanities and the Arts, The Australian National University, Canberra, ACT 0200, Australia sally.may@anu.edu.au, u4129920@anu.edu.au

${ }^{3}$ Research School of Earth Sciences, The Australian National University, Canberra, ACT 0200, Australia stewart.fallon@anu.edu.au

${ }^{4}$ Archaeology and Natural History, School of Culture, History and Language, College of Asia and the Pacific, The Australian National University, Canberra, ACT 0200, Australia daryl.wesley@anu.edu.au

${ }^{5}$ Kakadu Health Services, PO Box 721, Jabiru, NT 0886, Australia ronaldlamilami@hotmail.com
}

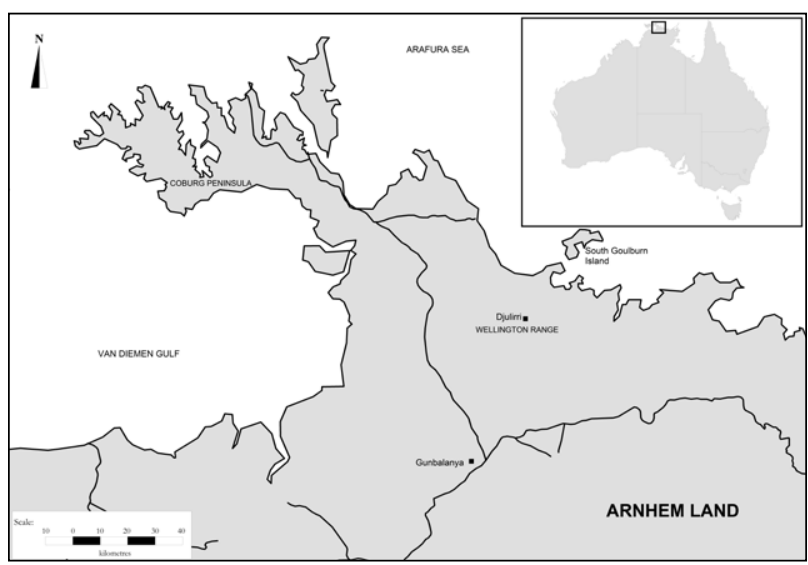

Figure 1 Map of western Arnhem Land with the Wellington Range study area and the location of Djulirri indicated.

funded projects. The first, Picturing Change, focuses on rock art produced during the 'contact' period (i.e. the period in which Aboriginal Australians began contact with visitors to their lands). While Picturing Change involves fieldwork in four key regions (Wollemi National Park, the Pilbara of Western Australia, central Australia, and western/northwestern Arnhem Land), this paper focuses on attempts to date contact imagery from Arnhem Land only and the significance of these findings to this Australia-wide initiative. The second project, Baijini, Macassans, Balanda, and Bininj: Defining the Indigenous Past of Arnhem Land through Culture Contact, is more focused on the Wellington Range and nearby coast. Besides rock art study, this project includes new excavations of rockshelters and Macassan stone lines. The dating of contact rock art imagery is central to both projects.

Djulirri is the largest art site documented in the Wellington Range. It forms part of the Maung language group's traditional territory and is located at the western side of senior traditional owner Ronald Lamilami's clan estate. Djulirri is considered one extremely large site by Aboriginal traditional owners. Each panel is less than $25 \mathrm{~m}$ from its neighbour, close enough to be considered part of the same site from an archaeological point of view. Photographer Axel Poignant was taken to the site by Lamilami's father, Lazurus, in 1952 (Lamilami 1974; Poignant 1995). During this visit, most likely the first by any non-Indigenous person, Poignant photographed key rock paintings shown to him by Lazurus and was told of their significance. In the 1970s, George Chaloupka (1993) photographed and described parts of Djulirri's main panels but further research did not take place until 2008 when an intensive recording programme of the entire site commenced (see May et al. 2010; Taçon et al. 2010). Across a $55 \mathrm{~m}$ length of dissected sandstone, Djulirri's main gallery was 


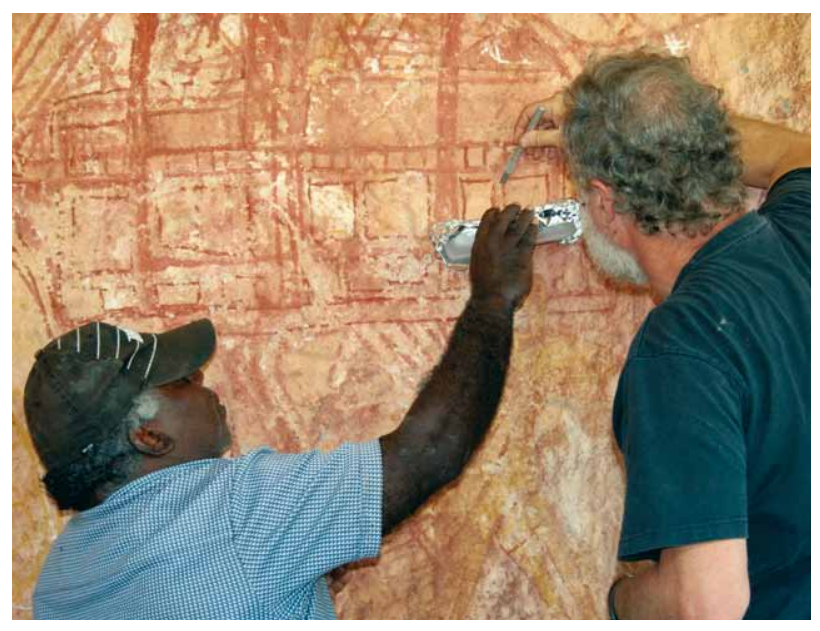

Figure 2 Ronald Lamilami and Paul Taçon collecting Djulirri beeswax samples superimposed on top of the tall ship, September 2008 (Photograph: Sally K. May). A third beeswax pellet located underneath the ship was collected from higher up the panel in 2009.

found to contain more than 1100 paintings, 17 stencils, one print, and 46 figures made from native beeswax in three adjacent wall/ ceiling areas (May et al. 2010). There are a further 52 panels with at least another 2000 examples of rock art, making it the largest known pigment site yet documented in Australia. The site is arranged in a horseshoe-like shape measuring c. $180 \mathrm{~m}$ by $120 \mathrm{~m}$, oriented roughly northwest-southeast, with a cluster of other sites nearby.

Paintings made with combinations of red, yellow, white and black pigment, typical of the region's recent rock art, including introduced contact period subject matter, are concentrated in Djulirri's main shelter and the rest of the southern wing of the horseshoe. Representative subject matter of all previous forms and styles, as differentially defined by Chaloupka (1993), Chippindale and Taçon (1998) Lewis (1988), and Taçon (1989), is concentrated in the northern wing, with a few mixed panels towards the back. It is within the main shelter that most of the beeswax art can also be found. A few of these designs lie over or under painted depictions of watercraft, including European tall ships and Southeast Asian sailing vessels (praus). As the dating of beeswax rock art has been shown to be both highly accurate and reliable (e.g. Bednarik 2001; Nelson 2000; Taçon et al. 2004), samples were obtained from a number of Djulirri figures with the intention of not only precisely dating those beeswax images but also obtaining minimum or maximum ages for diagnostic contact period paintings superimposed over or under the beeswax figures.

\section{Beeswax Rock Art Dating Programme}

Beeswax designs, made from the highly resinous 'wax' of native bees, are found in rockshelters across the north of the Northern Territory (Nelson 2000) and in the Kimberley region of Western Australia (Morwood et al. 2010). They are usually small, less than $30 \mathrm{~cm} \times 20 \mathrm{~cm}$, but occasionally cover over $1 \mathrm{~m}^{2}$ of a shelter's wall or ceiling. Most designs are geometric, often consisting of lines or parallel lines of small pellets (rounded blobs that when pressed onto the rock surface resemble raised dots). Occasionally strips, small sheets and/or pellets were used to form bird tracks and figurative motifs. Humanlike figures are common but sometimes animals, objects and mythical beings were portrayed (Gunn and Whear 2008; Nelson 2000; Taçon et al. 2004). Beeswax designs were usually made soon after wax was collected (Nelson 2000; Taçon and Garde 2000). Thus they are ideal for radiocarbon dating not only because they contain much carbon from a known source but also because the production of imagery was close to the onset of radioactive decay.

Brandl (1968) was the first to recognise the potential of dating beeswax rock art designs but it was not until the 1990s that the first dating attempts were made (Nelson et al. 1993, 1995), sparking an intensive dating programme across the Top End of the Northern Territory (Nelson 2000; Taçon et al. 2004). Early beeswax studies dated beeswax figures themselves, although their potential for dating overlying and underlying painted figures was acknowledged. More recent studies have tried to better link dating attempts to chronological change in both pigment and beeswax imagery (e.g. Gunn and Whear 2008; Morwood et al. 2010). About 200 separate beeswax figures have now been radiocarbon dated (Langley and Taçon 2010).

The oldest beeswax dates obtained from both Arnhem Land and the Kimberley are close to 4000 BP (Nelson et al. 1995; Morwood et al. 2010; Watchman and Jones 2002). However, most beeswax dates, from the north Kimberley across to central Arnhem Land, are less than 2000 years, with $90 \%$ less than 650 years. This appears to be related to taphonomy, although there may have been various peaks and declines in beeswax art production (Bednarik 2001). Taçon et al. (1997:958) argue that specific contact period beeswax motifs relate to sorcery in the Keep River region while Gunn and Whear (2008) used beeswax dating to show that depictions of Namarrkon, the Lightning Man, go back at least 150 years.

\section{Djulirri Sampling and Analysis Methodology}

On 28 September 2008, seven small samples of beeswax were obtained by Taçon and Lamilami from five Djulirri figures for dating (Figure 2). All were cut from the wall with a sterile scalpel and captured with a tray lined with fresh aluminium foil. Samples were then transferred to individual foil packets, given unique codes and placed in plastic bags. These samples were processed and dated at the SSAMS Radiocarbon Dating Centre of The Australian National University, Canberra. Three further samples were taken on 20 August 2009 for cross-checking.

The 2008 samples consisted of two pieces of beeswax (WRDJ1 , WRDJ-2) from a human figure covered by a yellow and orange painting of an emu; two beeswax pellets (WRDJ-3, WRDJ-4) over a painting of a European tall ship; one piece of beeswax (WRDJ5) from a beeswax figure that has hands on hips and wears a hat; one piece of beeswax (WRDJ-6) from a snake that overlies a large yellow painting of a prau; and a final piece (WRDJ-7) from a female human-like figure over a white painting of a prau. The motifs identified as 'praus' are argued to be depictions of Southeast Asian sailing vessels, rather than Chinese junks or European watercraft, because of their distinctive tripod masts (palayarang in Makassarese) and rectangular sails (sombala) (see Chaloupka 1996:137). In 2009, a piece of beeswax (WRDJ8) was obtained from a beeswax line above the beeswax snake and over the white prau and a second piece (WRDJ-9) was sampled from part of the beeswax snake that is on top of the 
Table 1 Radiocarbon age determinations from beeswax sampled at Djulirri.

\begin{tabular}{|c|c|c|c|c|c|}
\hline Sample & $\begin{array}{l}\text { Lab. No. } \\
\text { (SANU-) }\end{array}$ & Age BP & $\begin{array}{l}\text { Median Age } \\
\text { (cal AD) }\end{array}$ & $\begin{array}{l}\text { Calibrated Age } \\
\text { (Gal AD) }\end{array}$ & $\begin{array}{l}\text { Probability } \\
(95.4 \%)\end{array}$ \\
\hline $\begin{array}{l}\text { WRDJ-1 (beeswax human figure under } \\
\text { painted emu) }\end{array}$ & 6816 & $240 \pm 25$ & 1662 & $\begin{array}{c}1529-1539 \\
1634-1677 \\
1765-1800 \\
1940-1951\end{array}$ & $\begin{array}{r}1.2 \% \\
63.8 \% \\
30.9 \% \\
4.1 \%\end{array}$ \\
\hline $\begin{array}{l}\text { WRDJ-2 (beeswax human figure under } \\
\text { painted emu) }\end{array}$ & 6817 & $195 \pm 25$ & 1773 & $\begin{array}{c}1653-1684 \\
1733-1807 \\
1929-1952 \\
\end{array}$ & $\begin{array}{l}24.2 \% \\
57.4 \% \\
18.3 \% \\
\end{array}$ \\
\hline $\begin{array}{l}\text { WRDJ-3 (beeswax pellet from unidentifiable } \\
\text { design over painting of European tall ship) }\end{array}$ & 6810 & $165 \pm 20$ & 1765 & $\begin{array}{c}1666-1694 \\
1727-1784 \\
1795-1813 \\
1839-1841 \\
1853-1858 \\
1862-1866 \\
1918-1952\end{array}$ & $\begin{array}{r}17.9 \% \\
48.9 \% \\
10.7 \% \\
0.4 \% \\
0.6 \% \\
0.5 \% \\
20.9 \%\end{array}$ \\
\hline $\begin{array}{l}\text { WRDJ-4 (beeswax pellet from unidentifiable } \\
\text { design over painting of European tall ship) }\end{array}$ & 6811 & $175 \pm 20$ & 1767 & $\begin{array}{c}1664-1690 \\
1729-1788 \\
1791-1810 \\
1925-1952\end{array}$ & $\begin{array}{l}19.1 \% \\
50.4 \% \\
10.9 \% \\
19.6 \%\end{array}$ \\
\hline $\begin{array}{l}\text { WRDJ-5 (beeswax human figure with hat and } \\
\text { hands on hips) }\end{array}$ & 6812 & $190 \pm 25$ & 1772 & $\begin{array}{c}1654-1686 \\
1731-1808 \\
1927-1952\end{array}$ & $\begin{array}{l}22.4 \% \\
58.7 \% \\
18.9 \%\end{array}$ \\
\hline $\begin{array}{l}\text { WRDJ-6 (beeswax pellet from large snake over } \\
\text { yellow painting of a prau) }\end{array}$ & 6813 & $280 \pm 25$ & 1577 & $\begin{array}{c}1517-1595 \\
1618-1664 \\
1788-1791\end{array}$ & $\begin{array}{r}55.0 \% \\
44.7 \% \\
0.3 \%\end{array}$ \\
\hline $\begin{array}{l}\text { WRDJ-7 (beeswax pellet from a female human- } \\
\text { like figure over white painting of a prau) }\end{array}$ & 6814 & $220 \pm 25$ & 1777 & $\begin{array}{c}1644-1681 \\
1738-1752 \\
1762-1802 \\
1937-1951\end{array}$ & $\begin{array}{r}42.8 \% \\
2.9 \% \\
44.2 \% \\
10.2 \%\end{array}$ \\
\hline $\begin{array}{l}\text { WRDJ-8 (beeswax pellet from a beeswax line } \\
\text { above snake and over white painting of a prau) }\end{array}$ & 10039 & $210 \pm 25$ & 1779 & $\begin{array}{c}1647-1682 \\
1737-1758 \\
1761-1804 \\
1936-1951\end{array}$ & $\begin{array}{r}33 \% \\
7.3 \% \\
45.0 \% \\
14.7 \%\end{array}$ \\
\hline WRDJ-8r (same as above) & 10312 & $165 \pm 25$ & 1769 & $\begin{array}{l}1665-1696 \\
1725-1786 \\
1792-1814 \\
1835-1877 \\
1917-1952\end{array}$ & $\begin{array}{r}17.7 \% \\
43.6 \% \\
11.2 \% \\
7.0 \% \\
20.5 \%\end{array}$ \\
\hline $\begin{array}{l}\text { WRDJ-9 (beeswax pellet from large snake over } \\
\text { yellow painting of a prau) }\end{array}$ & 10206 & $230 \pm 25$ & 1682 & $\begin{array}{c}1641-1680 \\
1740-1741 \\
1763-1801 \\
1938-1951\end{array}$ & $\begin{array}{r}53.3 \% \\
0.3 \% \\
39.5 \% \\
7.0 \%\end{array}$ \\
\hline WRDJ-9r (same as above) & 10313 & $225 \pm 30$ & 1769 & $\begin{array}{c}1642-1684 \\
1739-1744 \\
1763-1802 \\
1938-1951\end{array}$ & $\begin{array}{r}48.0 \% \\
1.0 \% \\
42.3 \% \\
8.7 \%\end{array}$ \\
\hline $\begin{array}{l}\text { WRDJ-10 (beeswax pellet from unidentifiable } \\
\text { design under painting of European tall ship) }\end{array}$ & 10205 & $285 \pm 25$ & 1568 & $\begin{array}{l}1515-1598 \\
1617-1662\end{array}$ & $\begin{array}{l}61.1 \% \\
38.9 \%\end{array}$ \\
\hline $\begin{array}{l}\text { WRDJ-10r } \\
\text { (same as above) }\end{array}$ & 10314 & $275 \pm 25$ & 1625 & $\begin{array}{c}1521-1591 \\
1620-1665 \\
1785-1793\end{array}$ & $\begin{array}{r}47.0 \% \\
51.0 \% \\
2.0 \%\end{array}$ \\
\hline
\end{tabular}

Table 2 Reproducibility of Canberra bulk beeswax sample collected in 2007.

\begin{tabular}{|l|c|c|}
\multicolumn{1}{|c|}{$\begin{array}{c}\text { Sample } \\
\text { WAXSTD-1 }\end{array}$} & 6807 & $108.27 \pm 0.29$ \\
\hline WAXSTD-2 & 6809 & $108.66 \pm 0.32$ \\
\hline WAXSTD-3 & 6407 & $108.90 \pm 0.50$ \\
\hline WAXSTD-4 & 6409 & $108.89 \pm 0.40$ \\
\hline WAXSTD-5 & 6410 & $109.11 \pm 0.36$ \\
\hline WAXSTD-6 & 10315 & $108.21 \pm 0.36$ \\
\hline WAXSTD-7 & 10404 & $108.74 \pm 0.31$ \\
\hline
\end{tabular}




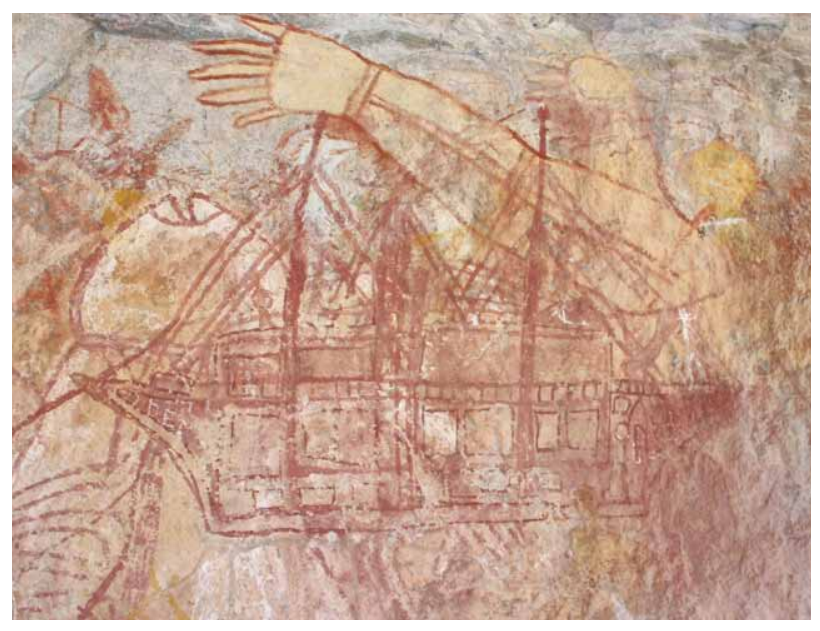

Figure 3 Painting of a European tall ship, most likely made in the 1700 s according to dating results (SANU-6810, SANU-6811, SANU-10205, SANU-10314) (Photograph: Paul S.C. Taçon). Note detailed rigging but lack of sails, suggesting the ship anchored off the coast.

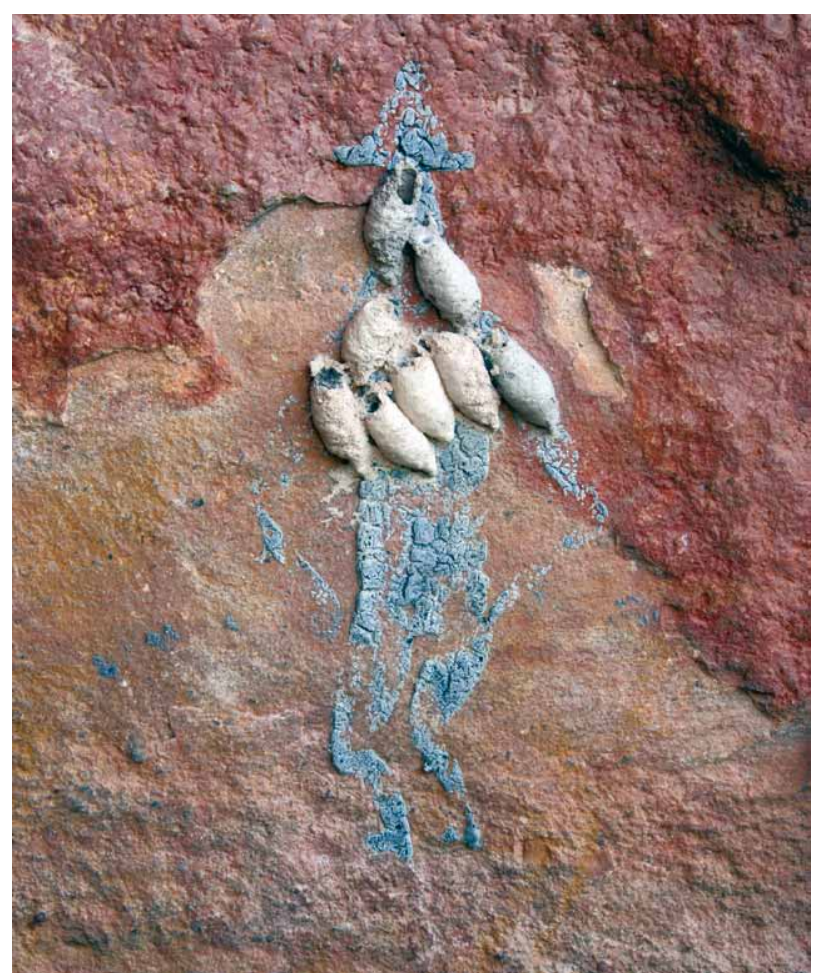

Figure 4 Beeswax figure with hands on hips and wearing a hat, probably made in the 1700s (1654-1808, median age 1772; SANU6812). Note that mud wasp nests overlie the figure (Photograph: Paul S.C. Taçon).

yellow prau's mast. A beeswax pellet (WRDJ-10) was also taken from an unidentifiable design superimposed under the tall ship sampled in 2008 .

\section{Radiocarbon Preparation}

Sample pre-treatment followed the protocol set out by Nelson (2000). Wax samples were removed from the foil packs in the laboratory and examined for particulate contaminants and transferred into clean glass vials and weighed. A subsample weighing $\sim 10 \mathrm{mg}$ was submerged in $0.25 \mathrm{~N} \mathrm{HCl}$ overnight at $\sim 23^{\circ} \mathrm{C}$. This removed the acid soluble contaminants. The samples were then rinsed with $18 \mathrm{M} \Omega$ water and placed in $0.05 \mathrm{~N} \mathrm{HaOH}$ for 2 hours. The solution was removed and the process was repeated. The samples were further rinsed with $18 \mathrm{M} \Omega$ water then subjected to an additional $0.25 \mathrm{~N} \mathrm{HCl}$ rinse to remove any carbonate formed during the $\mathrm{NaOH}$ cleaning step. The remaining sample was then rinsed 3 times in $18 \mathrm{M} \Omega$ water and dried overnight in a vacuum freeze drier. Around $3 \mathrm{mg}$ of sample material was loaded into a quartz tube with a piece of silver wire and $\mathrm{CuO}$. The tube was then sealed under vacuum and the sample combusted at $900^{\circ} \mathrm{C}$ for 4 hours.

The $\mathrm{CO}_{2}(\sim 1 \mathrm{mg}$ carbon) was then converted to graphite in the presence of Fe powder and $\mathrm{H} 2$ gas (water being removed during reaction with $\mathrm{Mg}\left(\mathrm{ClO}_{4}\right)_{2}$. Samples were run on the Single Stage Accelerator Mass Spectrometer (SSAMS) at the Research School of Earth Sciences, The Australian National University. Samples were normalised to Oxalic Acid-I and a coal blank was subtracted from the individual samples.

\section{Radiocarbon Dating Results}

Radiocarbon ages are reported in Table 1 . They were calibrated to calendar ages using Calib 6.0 (Stuiver and Reimer 1993) and IntCal09 (Reimer et al. 2009). Median ages were calculated using OxCal 4.1 (Bronk Ramsey 2009) and IntCal09. Duplicate samples were run on beeswax collected from the Djulirri panel in 2009 (WRDJ-8, -9, -10). Seven measurements of local (modern) beeswax, collected in Canberra, Australia in 2007, were run as a control (Table 2). These returned consistent ages showing the robustness of the beeswax sample preparation for AMS radiocarbon analysis.

As can be seen in Table 1, the results for samples of beeswax taken from different parts of the human-like beeswax figure superimposed underneath the yellow and orange emu (SANU16, SANU-17) are consistent with each other, indicating the emu painting was made sometime after between AD 1634 and 1807 (94.7\% for SANU-6816; 81.6\% for SANU-6817) and, based on median ages, probably after between 1662 and 1773 . This is important as it provides a chronological date for part of the most recent Djulirri rock art sequence, enabling us to determine the approximate age of several styles that immediately precede or follow the emu.

The samples taken from under the tall ship (SANU-10205, SANU-10314; Figure 3) indicate the painting can be no older than the early 1500 s to the mid-1600s (median ages of 1568 and 1625). Samples from over the tall ship (SANU-6810, SANU6811) suggest the painting has a minimum age of between 1664 and 1813 (94.7\% for SANU-6816; 81.6\% for SANU-6817), and probably $1765-1767$ (median ages). This is surprising as it was assumed the painting would have been made after frequent visits to the area by Europeans from 1818 onward, commencing with Phillip Parker King's ship The Mermaid (King 1826; Smith 1992) and a peak of activity in the late 1830 s to the late 1840 s when Victoria Settlement in nearby Port Essington was active (see Spillett 1972).

The early (pre-1813 and most probably 1700s) age throws open the possibility it is a depiction of a Dutch tall ship rather than a British one. For instance, Lieutenant J. Gonzalsee made contact with Aboriginal people in the Gulf of Carpentaria in 1756 (Mulvaney and Kamminga 1999:423) after earlier Dutch visits along the northern shores of Arnhem Land that began with the Arnhem in 1623. A second, similar looking painting of a tall ship lies partly under a few layers of more recent paintings 


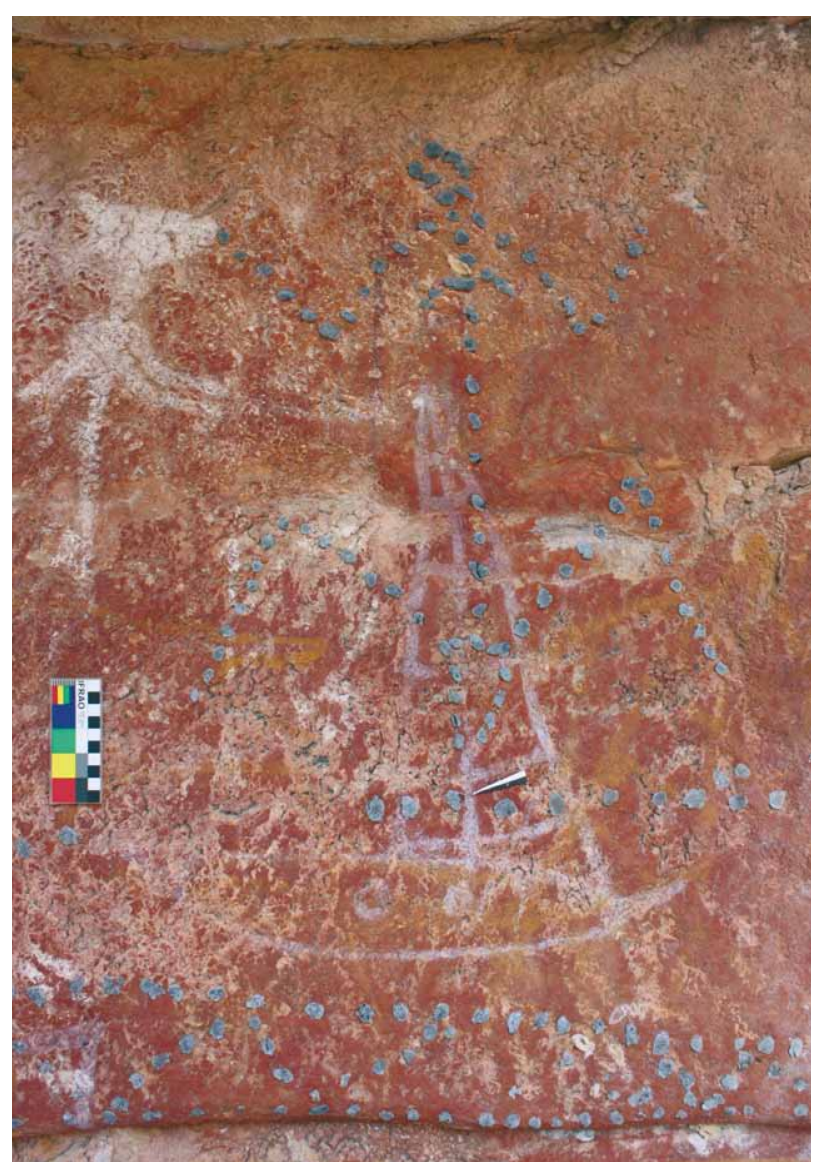

Figure 5 Beeswax female human-like figure and line, each composed of pellets and over a white painting of a prau, dated to between 1644 and 1814 (median age 1777). This provides a minimum age for the prau (SANU-6814, SANU-10039, SANU-10312) (Photograph: Paul S.C. Taçon).

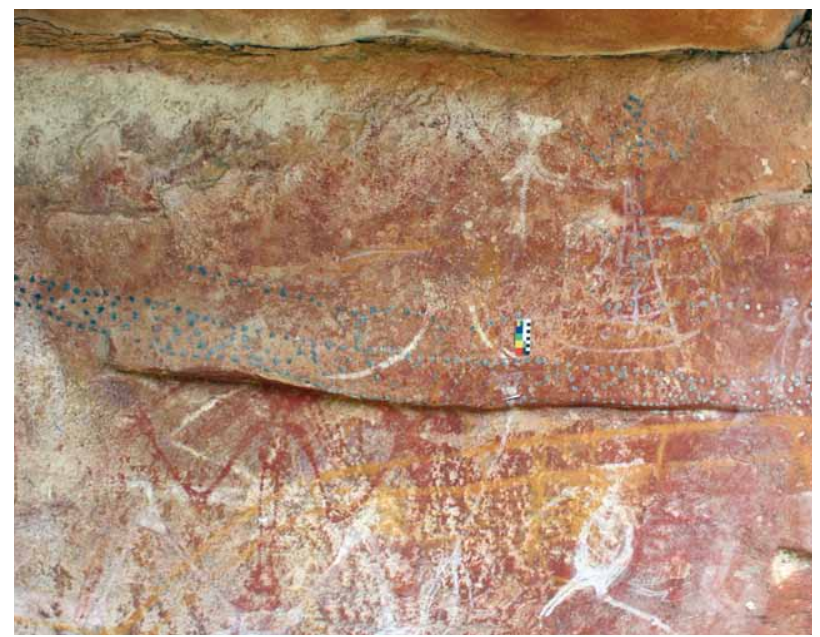

Figure 7 Djulirri main gallery panel with large beeswax snake over yellow painting of a prau. Scale is between the white and yellow praus; the snake's head is at the far middle left (Photograph: Paul S.C. Taçon).

but is not superimposed by beeswax. Based on its manner of depiction (form, style, colour, technique) it likely was made at the same time as the dated ship, probably by the same artist. Whether the paintings represent the same ship, a visit by two ships at the same time or two ships visiting at slightly different times is uncertain. Both ships are shown with extensive rigging but no sails, as if anchored offshore. Given the detailed portrayal

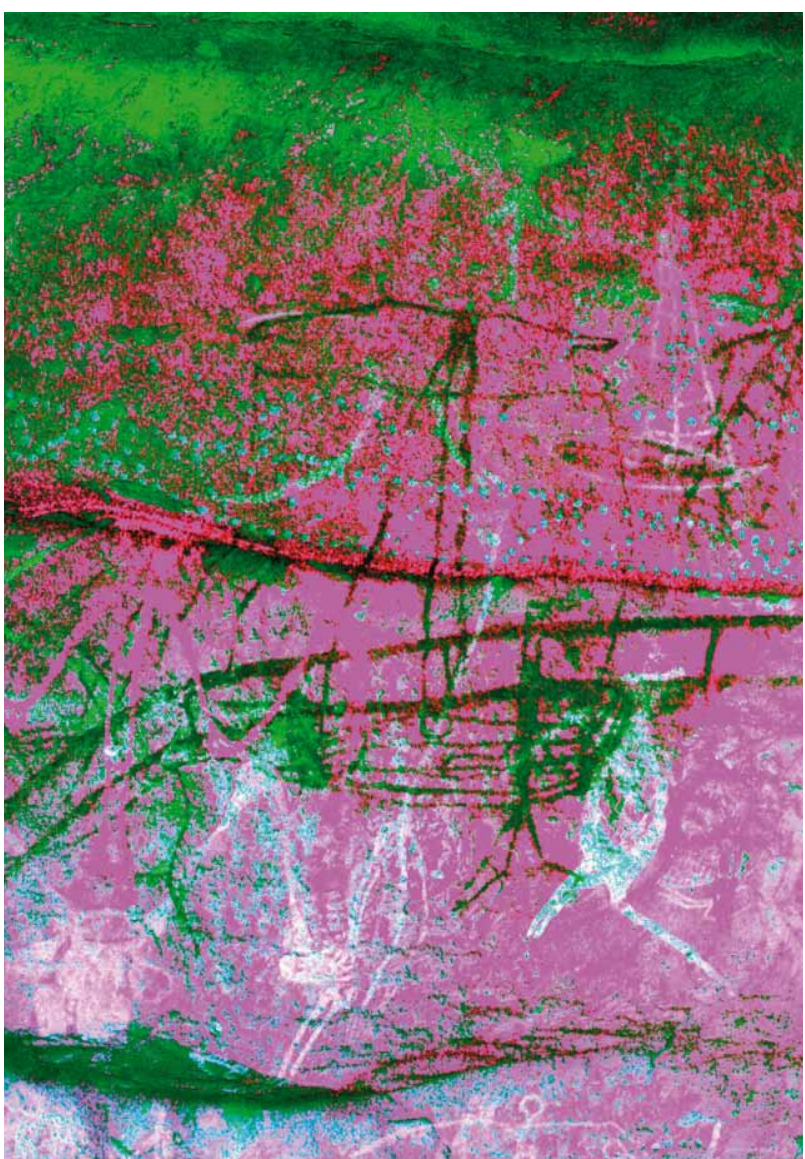

Figure 6 The panel with painted Southeast Asian sailing vessels (praus), with distinctive tripod masts and rectangular sails, after manipulation with the D-stretch software programme (see Gunn et al. 2010). Beeswax over the larger prau (originally in yellow) was dated to between 1517 and 1664, with a median age of 1577 (SANU-6812) (digital drawing from photograph by Sally K. May).

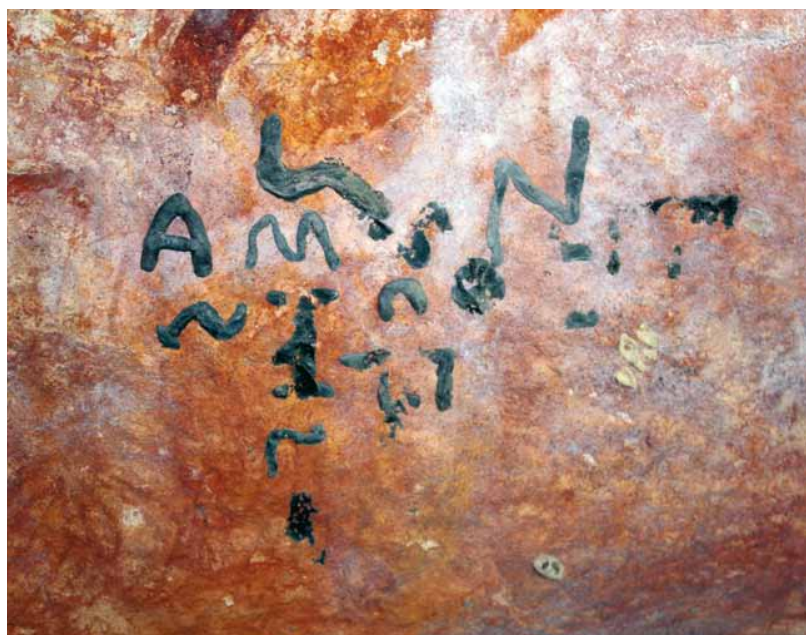

Figure 8 The most recent episode of beeswax art-making includes letters of the alphabet. It probably occurred in the early to mid-1900s (Photograph: Paul S.C. Taçon).

of both the external and internal features of the ships, the artist was obviously very familiar with such vessels. There are two pink human figures wearing hats and with hands on hips shown on the deck of the dated ship that are part of the original composition. Two others in white, along with a red 'smoke stack' in the middle of the dated ship, were added later as these features can clearly be seen superimposed over the top. 
The beeswax human figure with hands on hips (SANU6812; Figure 4) was probably made between the mid-1600s and 1808 (81.1\% probability; median age 1772). It is the earliest dated surviving depiction of someone from outside Arnhem Land: a European sailor, a visiting Macassan, or someone else from a foreign land. Alternatively, it could be a representation of a local Aboriginal person wearing a hat received through trade and mimicking a foreigner. However, Indigenous peoples of various parts of northern Australia and Southeast Asia often depicted Europeans at rock art sites with hands resting on their hips (e.g. for the Pilbara and Arnhem Land see Taçon et al. in press and for the Semang see Mokhtar and Taçon in press). Importantly, when human figures presumed to be depictions of Southeast Asians are shown on praus they do not have hands on hips. The age estimate of the beeswax figure accords well with that of the tall ship. Both images suggest a close encounter between local Aboriginal people and Europeans, probably in the 1700 s.

The minimum age estimates for one of the praus was also surprising. A sample recovered in 2008 revealed that the white prau (SANU-6814; Figure 5) was probably made prior to 1802 (89.9\% probability that the beeswax over it was made between 1644 and 1802, median age 1777). The yellow prau (SANU6813; Figures 6 and 7), on the other hand, is much older. Results indicate it was made sometime prior to 1664 and possibly earlier than 1517 (99.7\% probability that the beeswax over it was made between $\mathrm{AD} 1517$ and 1664). The median age of the beeswax superimposed over the yellow prau is 1577 . This is earlier than even the most liberal estimates of when Macassans are thought to have first begun trepanging in northern Australia (see discussion below).

Samples taken in 2009 confirm the results for the white prau (SANU-10039, SANU-10312), strongly suggesting the painting was made in the 1700s, but the beeswax pellet over the yellow prau (SANU-10206, SANU-10313) has an age statistically similar to all of the beeswax samples from over the white prau. As it is close to the beeswax line and female figure that are superimposed over the white prau it was probably placed over the yellow prau during this more recent beeswax art-making episode. The addition of beeswax to earlier images has been observed at other Arnhem Land sites with dated beeswax (e.g. Taçon and Garde 2000:72). However, results suggest there is a $50 \%$ chance the minimum age for this pellet overlying the yellow prau painting is between 1641 and 1684 .

If we compare all of the ages for the beeswax sampled for dating, the results appear to indicate there were three main beeswax art-making episodes: the first between 1517 and 1595, the second between 1618 and 1694 and the third from 1727 and 1814. Alternatively, the results may also mean there was an ongoing practice of making beeswax art since at least the early 1500s. At Djulirri there was also some beeswax art-making post1915 as beeswax was used to make letters of the alphabet that would have been learned at Mission schools (Goulbourn Island Methodist Mission was established in 1915, see Lamilami 1974; CMS Oenpelli Mission was established in 1925, see Cole 1975:1835). These designs (e.g. Figure 8) appear much fresher and are darker in colour but were not sampled for radiocarbon dating (see Nelson 2000 for beeswax age in relation to colour, with darker beeswax invariably younger).
Importantly, beeswax from the earliest episodes are under the painting of the European tall ship but over the yellow Macassan prau. In other words, the beeswax age estimates are in sequence in relation to historically-documented events. Another important observation is that all beeswax designs dated were made after the arrival of non-Aboriginal people to Arnhem Land shores whereas further south in Arnhem Land there are much older examples of beeswax (Nelson 2000; Nelson et al. 1995; Taçon et al. 2004; Watchman and Jones 2002). It is tempting to conclude that beeswax art-making in the Wellington Range only began when groups to the south travelled up to the coast to interact with foreigners (e.g. Earl 1846; Spillett 1972), introducing the technique to the local inhabitants when they camped at particular sites together. However, more research and the dating of figures with an older appearance is needed to support this.

\section{Significance of Minimum Ages for Praus}

One finding stands out above all others from this beeswax dating programme: a painting of a prau was found to have a minimum age of $\mathrm{AD} 1664$, and could be much older. This result is in contrast to historical evidence relating to when praus from Indonesia began to visit the coast of the Northern Territory for the purpose of collecting trepang, supported by recent archival research (Macknight 2008). Other studies undertaken by a number of researchers have resulted in several contrasting views of chronology, based on documentary evidence, Indigenous narrative and excavated archaeological evidence.

Based on documentary evidence, Campbell Macknight (1976:97, 1986:69) initially placed the origins of the Macassan trepang industry between AD 1650 and 1750. However, he later revised his evaluation, arguing the industry was not in full swing until the 1780s, with some possible earlier excursions to north Australia occurring from the 1750s. Macknight's initial evaluation was based on a number of written sources which each date the industry to the eighteenth century, including historical accounts, personal journals and government records. His re-evaluation (Macknight 2008) is from evidence presented by Knapp and Sutherland's (2004) study of detailed trade data for Makassar.

In 1801, Matthew Flinders wrote that Pobassoo, spokesman for a fleet of six praus whom he met in 1803, 'had made six or seven voyages from Macassar to this coast, within the preceding twenty years, and he was one of the first who came' (Flinders 1814, 2:231; Macknight 1969:376). This statement by Pobassoo has been interpreted to mean that the Macassan industry began around 1783, although Englishman Alexander Dalrymple suggested the industry was in progress during the early 1760s. Specifically, according to a passage written by Dalrymple, the Macassans had already reached New Holland by 1769: 'They have penetrated to New-Holland on the south, and to Papua on the east; they also voyage to Bencoolen, Quedah, Manila, and to all the intermediate countries' (Dalrymple 1769:83; Macknight 1969:viii). Additionally, records of Captain Thomas Forrest document that 'I have been told by several Buggesses, that they sail in their Paduakans to the northern parts of New-Holland, possibly Carpentaria Bay, to gather Swallow (Biche de mer), which they sell to the annual China Junk at Macassar' (Forrest 1792:82-83; Macknight 1969:382). According to Macknight (1969:382), Forrest's records may be contemporary with that of Dalrymple's account. 
The trepang 'industry' and, more specifically, Macassan or Bugis praus visiting Australia, are mentioned in sources from the eighteenth and nineteenth centuries. Conversely, accounts from earlier centuries exhibit a distinct lack of reference to the industry, i.e. accounts of the seventeenth century Dutch explorers in the area (Arnhem 1623 and Tasman 1644) make no mention of the Macassans and, as a result, no information about the industry can be inferred (Sharp 1963:52-54, 88-91; Macknight 1969:384-385). Mitchell (1994:42) and Mulvaney and Kamminga (1999:415) suggest that the first positive written reference to Macassans dates from 15 October 1754, consisting of a letter from the Governor General of the East Indies to the managers of the Dutch East India Company of Amsterdam: 'The Southland which is in the southeast of Timor not far from thence, is made now and then from Timor and Makassar, but produces so far [as] we know nothing but trepang, being dried jelly-fish, and wax' (see Mitchell 1994:42).

Although there is a lack of documentary evidence for an earlier date, Ronald and Catherine Berndt (1947) argued that the trepang industry in northern Australia must have begun in the sixteenth century based on ethnographic fieldwork. Specifically, they suggest that there was 'early Macassan or late pre-Macassan (Baijini) contact, in perhaps the first part of the sixteenth century' (Berndt and Berndt 1947:133). Their argument appears to be based upon the significant influence of Macassans on local Aboriginal culture and language.

Earlier culture contact in the region is supported by McIntosh (1996, 2006, 2008) who reviewed Yolngu narratives regarding the Baijini. According to McIntosh (2006) the mythological evidence points to ongoing visitation and exchange between the inhabitants of Arnhem Land and those from the Indonesian archipelago for a longer period than indicated by European records. Ganter (2006:7) supports this position stating that it is reasonable to expect that the trepang industry was 'grafted onto prior local knowledge' of the existence of resources in northern Australia. Clarke (2000a:327) suggests that although historical accounts may be correct in dating the trepang industry to the mid-seventeenth century, it is 'possible that earlier visits involved smaller numbers of people and ships, and a different range of commodities such as sandalwood, pearl shell and turtle shell' that may have been sought by the Macassans or others.

McIntosh (2008:178) proposes the Baijini may be Bugis exiled from the Kingdom of Gowa in 1667 after Dutch occupation. The rise of the Kingdom of Gowa saw a number of attempts to secure the eastern trading routes with successive expeditions against numerous islands, including Sumbawa, Lombok, Buton and Timor (Pelras 1996:139). There was also the growing slave trade throughout the Indonesian archipelago in the 1600s which may have motivated visits to north Australia (Pelras 1996:119). And there is ample evidence of the growing seafaring capability and power of Macassans during the 1600s that would have led to expeditions to northern Australia. For instance, in 1606 Spaniards Luis Vaez Torres and Diego de Prado sailed through the Torres Strait from east to west. Near West Irian Torres encountered 'Moors', 'Islamic Traders' thought to be Buginese or Macassan (Mulvaney 1989:9-10). The serendipitous find of a Portuguese earthenware jar in Darwin Harbour, Northern Territory dated to 490 years BP $+/-25 \%$ (AD 1513 \pm 80 ) is further evidence of early visitations (Weekend Australian 1 April 2007).
Although Macknight is of the opinion that the trepang industry began around AD 1780 there are still problems with his archaeological evidence for Macassan visits to Australia that need to be discussed in the context of this paper. This is because radiocarbon dates on wood charcoal found in the remains of Macassan trepang boiling fireplaces returned dates several hundred years older than ages inferred by documentary evidence. The wood was assumed to be mangrove wood but the charcoal samples were not subjected to species identification. Charcoal samples with very early ages dated by Macknight (1969:388) include two from Anuru Bay, about $28 \mathrm{~km}$ northeast of Djulirri (S.L. 7: 500 75 BP [ANU-316], AD 1450; S.L. 17: $740 \pm 70$ BP [ANU-240], AD 1210), one from Entrance Island (buried S.L.: $830 \pm 80$ BP [ANU-242], AD 1120) and two from Lyäba, Groote Eylandt (S.L. 8: 430 \pm 70 BP [ANU-317], AD 1520; S.L. 13: 780 \pm 75 BP [ANU-241], AD 1170).

As can be seen, three geographically separate sites (Anuru Bay, Lyäba on Groote Eylandt and Entrance Island) returned radiocarbon dates with ages of approximately 500-800 BP, or AD 1170-1520 (Macknight 1976:98-99). Due to the discrepancy between these dates and historical accounts, Macknight argued that there must be a systematic source of error in the archaeological dates, although he originally stated that 'the samples themselves are all of excellent quality ... it is difficult to think of any source of contamination' (Macknight 1969:388). Macknight was also certain of the stratigraphic relationship between the dated 'mangrove' wood charcoal and the stonelines, suggesting that misidentification was impossible (Macknight 1969:390). Mitchell (1994) calibrated Macknight's radiocarbon dates using the Calib 2.0 software programme. After calibration (at 2-sigma), the dates returned age estimates as old as the eleventh century $\mathrm{AD}$, and all but one occurring outside the range of documentary evidence. However, Mitchell (1994) argued that the radiocarbon dates are unreliable and that they result from technical problems with radiocarbon analysis of 'mangrove' wood. He states that there is 'specific evidence' that both 'presample growth error' and 'marine reservoir effect' could influence radiocarbon dates on mangrove wood and account for the discrepancy between the historical data and these radiocarbon dates (Mitchell 1994:54-56).

Critical to 'pre-sample growth error' theory is that different parts of a long-lived perennial plant can differ in age considerably, sometimes by centuries. Specifically, the outermost growth rings of a tree would yield radiocarbon ages close to the death of the tree, while the internal hardwood of trees would return ages older than the death of the tree (Mitchell 1994:54). Mitchell (1994:54) argues that the pre-sample growth error may have introduced an element of bias towards excessive antiquity on some of the radiocarbon dates from Macassan sites'.

Mitchell (1994:54-56) also suggests that an oceanic reservoir correction factor needs to be taken into account due to the absorption of inorganic carbonates from inundated sediments by mangroves and the problems that arise because different carbon reservoirs can contain different initial concentrations of ${ }^{14} \mathrm{C}$. However, there appears to be no evidence to support this for mangrove wood as these trees absorb their carbon from the air like most trees and not from water. The marine reservoir effect usually occurs with shells, coral and other marine organisms (e.g. Southon et al. 2002; Ulm et al. 2009). In this regard, Clarke 
(2000a:327) states that although there may be a systematic source of error in each of the radiocarbon dates it is clear that a more rigorous program to test these likely sources should be applied before accepting some dates and not others'. However, it is possible Macknight dated an earlier Indigenous occupation of the areas later occupied by Macassans.

In addition to the radiocarbon dates outlined above, a small pottery sherd at Dadirringka rockshelter, Groote Eylandt, was found $7 \mathrm{~cm}$ below where a date of $930 \pm 60$ BP (ANU-8984) calibrated to between $904-731$ BP was obtained, providing more evidence for an earlier age for contact with outsiders (Clarke and Frederick 2009:14). Clarke (1994) found further archaeological evidence in support of early contact between Aboriginal Australians and Southeast Asians from an analysis of material excavated at Malmudinga, Groote Eylandt. Clarke observed a sequence of changes in resource use that fits in with the general direction of changes observed within known contact period middens. Clarke argues that Unit 2 at Malmudinga could be interpreted to represent an increase in the intensity and duration of site use through a greater discard rate of shell and the targeting of sand/mud shellfish species that can be attributed to contact with earlier Indonesian seafarers (Clarke 1994:181; see also Clarke 2000b:168-170). Clarke dates this early contact to between 1000 and 900 years ago at this site. However, she states that 'this initial contact was not necessarily of the order of magnitude of the later trepang industry, organised from the city of Macassar and may have been both sporadic and small scale' (Clarke 1994:470).

\section{Conclusions}

This research not only illustrates the usefulness of dating beeswax figures to obtain minimum or maximum ages for paintings at sites with multiple layers of imagery but also has contributed to debates about when Asians and Europeans first visited Australia, as well as the impact such visits had on local inhabitants (e.g. Veth et al. 2008). Chaloupka (1996), Clarke and Frederick (2006, 2008) and others have highlighted the importance of depictions of Macassan vessels at north Australian rock art sites but until now there has been little confirmation of their age. The painting of the yellow prau at Djulirri made prior to AD 1664 is the oldest dated contact rock art depiction from anywhere in Australia, the oldest rock art image with Southeast Asian subject matter and some of the earliest evidence for Southeast Asian visits to northern Australia.

Ironically, archaeological excavation evidence has long pointed to this contact occurring prior to the 1700 s but has generally been dismissed due to contradiction with the historical records. This reliance on historical records is unusual given that one of the strengths of archaeology is the ability to add to or contradict historical records, which are often flawed, biased, selective and missing in detail. This new archaeological evidence (i.e. a minimum age for a Southeast Asian sailing vessel, European tall ship and a depiction of a non-Aboriginal person) can complement the already existing archaeological evidence, helping to refocus debate towards a reading of the data as opposed to the manipulation of data to fit preconceived ideas of contact.

The nature of early contact between Aboriginal people and Europeans in Arnhem Land also needs reassessment as the dating of a beeswax human figure wearing a hat and with hands on hips, as well as minimum and maximum ages for a painting of a tall ship, suggests a close encounter between local Aboriginal people and Europeans probably occurred in the 1700s and certainly before 1813. Exactly which European group - English, Dutch, Portuguese, Spanish - are possible candidates for the ship are the subject of further research.

Developing a clear understanding of when Asian and European peoples first started visiting northern Australia in the recent past is not an impossible task. There is ample archaeological evidence from which to undertake a new assessment and this study has shown that rock art clearly has a contribution to make.

\section{Acknowledgements}

We would like to thank the Lamilami family for their support, guidance and enthusiasm throughout fieldwork from 2008 to 2010. Picturing Change is funded by ARC Discovery Grant DP0877463 and we would like to acknowledge June Ross and Alistair Paterson as fellow Chief Investigators on this project. Fieldwork was undertaken in conjunction with Daryl Wesley and Sue O'Connor's ARC-funded project Baijini, Macassans, Balanda, and Bininj: Defining the Indigenous Past of Arnhem Land through Culture Contact (LP0882985). Many of the ideas for this paper were developed during camp conversations and we thank all the many volunteers who assisted us in recording rock art and undertaking wider archaeological surveys and excavations in 2008 and 2009. Michelle Langley provided some research assistance. Kelly James is thanked for radiocarbon dating assistance. The digital drawing is by Sally K. May while the map is by Mel Marshall. Four referees and the editors of Australian Archaeology are thanked for comments that improved the paper. Finally we would like to acknowledge our own institutions, Griffith University and The Australian National University, for their support of our research.

\section{References}

Bednarik, R. 2001 The taphonomy of beeswax figures. Rock Art Research 18(2):91-95. Berndt, R. and C. Berndt 1947 Discovery of pottery in north-eastern Arnhem Land. Journal of the Royal Anthropological Institute of Great Britain and Ireland 77:133-138.

Brandl,E. 1968 Aboriginal rock designs in beeswax and description of cave painting sites in western Arnhem Land. Archaeology and Physical Anthropology in Oceania 3:19-29.

Bronk Ramsey, C. 2009 Bayesian analysis of radiocarbon dates. Radiocarbon 51(1):337-360.

Chaloupka, G. 1993 Journey in Time. Chatswood: Reed Books.

Chaloupka, G. 1996 Praus in Marege: Makassan subjects in Aboriginal rock art of Arnhem Land, Northern Territory, Australia. Anthropologie 34(1-2):131-142.

Chippindale, C. and P.S.C. Taçon 1998 The many ways of dating Arnhem Land rock-art. In C. Chippindale and P.S.C. Taçon (eds), The Archaeology of RockArt, pp.90-111. Cambridge: Cambridge University Press.

Clarke, A. 1994 Winds of Change: An Archaeology of Contact in the Groote Eylandt Archipelago, Northern Australia. Unpublished PhD thesis, The Australian National University, Canberra.

Clarke, A. 2000a 'The Moormans Trowsers': Aboriginal and Macassan interactions and the changing fabric of Indigenous social life. In S. O'Connor and P. Veth (eds), East of Wallace's Line: Studies of Past and Present Maritime Cultures of the Indo-Pacific Region, pp.315-335. Rotterdam: A.A. Balkema. 
Clarke, A. 2000b Time, tradition and transformation: The negotiation of crosscultural engagements on Groote Eylandt, northern Australia. In R. Torrence and A. Clarke (eds), The Archaeology of Difference: Negotiating Cross-Cultural Engagements in Oceania, pp.142-181. One World Archaeology 38. London: Routledge.

Clarke, A. and U. Frederick 2006 Closing the distance: Interpreting cross-cultural engagements through indigenous rock art.In I.Lilley (ed.), Archaeology of Oceania: Australia and the Pacific Islands, pp.116-133. Oxford: Blackwell Publishing.

Clarke, A. and U. Frederick 2008 The mark of marvelous ideas: Groote Eylandt rock art and the performance of cross-cultural relations. In P. Veth, P. Sutton and M. Neale (eds), Strangers on the Shore: Early Coastal Contacts in Australia, pp.148-164. Canberra: National Museum of Australia Press.

Clarke, A. and U. Frederick 2009 Making a Sea Change: Rock Art, Archaeology and the Enduring Legacy of Frederick McCarthy's Research on Groote Eylandt. Paper to Barks, Birds and Billabong Symposium, 18 November, National Museum of Australia, Canberra.

Cole. K. 1975 A History of Oenpelli. Darwin: Nungalinya Publications.

Dalrymple, A. 1769 A Plan for Extending the Commerce of this Kingdom and of the East-India-Company. London: J. Nourse and T. Payne.

Earl, A. 1846 On the Aboriginal tribes of the northern coast of Australia. Journal of the Royal Geographic Society of London 16:239-251.

Flinders, M. 1814 A Voyage to Terra Australis ... in the Years 1801, 1802, and 1803 ... 2 vols and Atlas. London: G.W. Nicol.

Forrest, T. 1792 A Voyage from Calcutta to the Mergui Archipelago, Lying on the East Side of the Bay of Bengal ... London: Robson, Owen and Balfour.

Ganter, R. 2006 Mixed Relations: Asian-Aboriginal Contact in North Australia. Perth: University of Western Australia Press.

Gunn, R.G., C.L. Ogleby, D. Lee and R.L. Whear 2010 A method to visually rationalize superimposed pigment motifs. Rock Art Research 27(2):131-136.

Gunn, R.G. and R.L. Whear 2008 A singular beeswax representation of Namarrkon, the Lightning Man, from western Arnhem Land. Australian Aboriginal Studies 2:54-69.

King, P.P. 1826 Narrative of a Survey of the Intertropical and Western Coasts of Australia. London: John Murray.

Knapp, G. and H. Sutherland 2004 Monsoon Traders: Ships, Skippers and Commodities in the Eighteenth Century. Leiden: KITLV Press.

Lamilami, L. 1974 Lamilami Speaks. Sydney: Ure Smith.

Langley, M.C. and P.S.C. Taçon 2010 The age of Australian rock art: A review. Australian Archaeology 71: 70-73.

Lewis, D. 1988 The Rock Paintings of Arnhem Land, Australia: Social, Ecological and Material Culture Change in the Post-Glacial Period. BAR International Series 415. Oxford: British Archaeological Reports.

Macknight, C.C. 1969 The Macassans: A Study of the Early Trepang Industry along the Northern Territory Coast. Unpublished PhD thesis, The Australian National University, Canberra.

Macknight, C.C. 1976 The Voyage to Marege': Macassan Trepangers in Northern Australia. Melbourne: Melbourne University Press.

Macknight, C.C. 1986 Macassans and the Aboriginal past. Archaeology in Oceania 21(1):69-75.

Macknight, C.C. 2008. Harvesting the memory: Open beaches in Makassar and Arnhem Land. In P. Veth, P. Sutton and M. Neale (eds), Strangers on the Shore: Early Coastal Contacts in Australia, pp.133-147. Canberra: National Museum of Australia Press.

May, S.K., P.S.C. Taçon, D. Wesley and M. Travers 2010 Painting history: Indigenous observations and depictions of the 'other' in northwestern Arnhem Land, Australia. Australian Archaeology 71: 57-65.

McIntosh, I.S. 1996 Can we be Equal in your Eyes? A Perspective on Reconciliation from North-East Arnhem Land. Unpublished PhD thesis, Northern Territory University, Darwin.
McIntosh, I.S. 2006 A treaty with the Macassans/Burrumarra and the Dholtji ideal. The Asia Pacific Journal of Anthropology 7(2):153-172.

McIntosh, I.S. 2008 Pre-Macassans at Dholtji? Exploring one of north-east Arnhem Land's greatest conundrums. In P.Veth, P. Sutton and M. Neale (eds), Strangers on the Shore: Early Coastal Contacts in Australia, pp.165-180. Canberra: National Museum of Australia Press.

Mitchell, S. 1994 Culture Contact and Indigenous Economies on the Cobourg Peninsula, Northwestern Arnhem Land. Unpublished PhD thesis, Northern Territory University, Darwin.

Mokhtar, S. and P.S.C. Taçon in press The recent rock drawings of the Lenggong Valley, Perak, Malaysia. Antiquity.

Morwood, M.J., G.L.Walsh and A.I.Watchman 2010 AMS radiocarbon ages for beeswax and charcoal pigments in north Kimberley rock art. Rock Art Research 27(1):3-8.

Mulvaney, D.J. 1989 Encounters in Place: Outsiders and Aboriginal Australians 16061985. St Lucia, QLD: University of Queensland Press.

Mulvaney, D.J. and J. Kamminga 1999 Prehistory of Australia. St Leonards, NSW: Allen and Unwin.

Nelson, D.E. (ed.) 2000 The Beeswax Art of Northern Australia [CD ROM]. Burnaby: Simon Fraser University.

Nelson, D.E., G. Chaloupka, C. Chippindale, M.S. Alderson and J.R. Southon 1995 Radiocarbon dates for beeswax figures in the prehistoric rock-art of northern Australia. Archaeometry 37(1):151-156.

Nelson, D.E., C. Chippindale, G. Chaloupka, P. Taçon and J.R. Southon 1993 AMS dating of beeswax rock-art in northern Australia. The Artefact 16:52.

Pelras, C. 1996 The Bugis. Oxford: Blackwell Publishers.

Poignant, R. 1995 Lost Conversations, Recovered Archives. Tenth Eric Johnston Lecture 1995. Occasional Paper 49. Darwin: Northern Territory Government. Retrieved 3 August 2009 from http//www.ntl.nt.gov.au/_data/assets/pdf_ file/0015/5262/occpaper49_ej10.pdf.

Reimer, P.J., M.G.L. Baillie, E. Bard,A. Bayliss, J.W. Beck, P.G. Blackwell, C. Bronk Ramsey, C.E. Buck, G.S. Burr, R.L Edwards, M. Friedrich, P.M. Grootes, T.P. Guilderson, I. Hajdas, T.J.Heaton, A.G. Hogg, K.A. Hughen, K.F. Kaiser, B. Kromer, F.G. McCormac, S.W. Manning, R.W. Reimer, D.A. Richards, J.R. Southon, S. Talamo, C.S.M. Turney, J. van der Plicht and C.E. Weyhenmeyer 2009 IntCal09 and Marine09 radiocarbon age calibration curves, 0-50,000 years cal BP. Radiocarbon 51:1111-1150.

Sharp, A. 1963 The Discovery of Australia. London: Clarendon Press.

Smith, K.V. 1992 King Bungaree: A Sydney Aborigine meets the Great South Pacific Explorers, 1799-1830. Kenthurst: Kangaroo Press.

Southon, J., M. Kashgarian, M. Fontugne, B. Metivier and W.W.-S. Yim 2002 Marine reservoir corrections for the Indian Ocean and Southeast Asia. Radiocarbon 44(1):167-180.

Spillett,P.G. 1972 Forsaken Settlement: An Illustrated History of the Settlement of Victoria, Port Essington North Australia 1838-1849. Dee Why West: Lansdowne Press.

Stuiver, M. and P.J. Reimer 1993 Extended ${ }^{14} \mathrm{C}$ data base and revised CALIB 3.0 age calibration program. Radiocarbon 35(1):215-230.

Taçon, P.S.C. 1989 From Rainbow Snakes to 'X-Ray' Fish: The Nature of the Recent Rock Painting Tradition of Western Arnhem Land, Australia. Unpublished PhD thesis, The Australian National University, Canberra.

Taçon, P.S.C., R. Fullagar, S. Ouzman and K. Mulvaney 1997 Cupule engravings from Jinmium-Granilpi (northern Australia) and beyond: Exploration of a widespread and enigmatic class of rock markings. Antiquity 71:942-965.

Taçon, P.S.C. and M. Garde 2000 Dating beeswax figures on rock: The view from central Arnhem Land. In G. Ward and C. Tuniz (eds), Advances in Dating Australian Rock-Markings: Papers from the First Australian Rock-Picture Dating Workshop, pp.71-75. Occasional AURA Publication 10. Melbourne: Australian Rock Art Research Association.

Taçon, P.S.C., M. Langley, S.K. May, R. Lamilami, W. Brennan and D. Guse 2010 Ancient bird stencils discovered in Arnhem Land, Northern Territory, Australia. Antiquity 84:416-427. 
Taçon, P.S.C., E. Nelson, C. Chippindale and G. Chaloupka 2004 The beeswax rock art of the Northern Territory: Direct dating results and a 'book of record'. Rock Art Research 21(2):155-160.

Taçon, P.S.C., J. Ross, A. Paterson and S. May in press Picturing change and changing pictures: Contact period rock art of Australia. In J. McDonald and P. Veth (eds.), A Companion to Rock Art. Oxford: Blackwell.

Ulm, S., F. Petchey and A. Ross 2009 Marine reservoir corrections for Moreton Bay, Australia. Archaeology in Oceania 44(3):160-168.
Veth, P., P. Sutton and M. Neale (eds) 2008 Strangers on the Shore: Coastal Contacts in Australia. Canberra: National Museum of Australia.

Watchman, A. and R. Jones 2002 An independent confirmation of the 4 ka antiquity of a beeswax figure in western Arnhem Land, northern Australia. Archaeometry 44(1):145-153. 